\title{
UJI ANTIBAKTERI BAWANG DAYAK (Eleutherine palmifolia(L) Merr) SECARA INFUSA TERHADAP BAKTERI Eschericia coli
}

\author{
${ }^{1}$ Indah Herlisya Ramadhani , ${ }^{2}$ Febri Nur Ngazizah , ${ }^{3}$ Nur Aini Hidayah Khasanah \\ ${ }^{1,2,3}$ Stikes Borneo Cendekia Medika Pangkalan Bun \\ email : indahherlisya@gmail.com
}

\begin{abstract}
Abstrak : Salah satu tanaman yang dapat digunakan untuk antibakteri adalah bawang dayak (Eleutherine palmifolia (L.) Merr.), merupakan tanaman herbal Kalimantan yang memiliki kandungan senyawa kimia flavonoid, alkaloid, glikosida, fenolik, kuinon, steroid, dan tannin. Senyawa tersebut memiliki kemampuan menghambat dan mematikan aktivitas bakteri. Salah satunya adalah bakteri Escherichia coli. E. coli biasanya hidup di usus manusia dan hewan. Uji antibakteri E. palmifolia dilakukan secara infusa menggunakan pelarut air. Metode ini dilakukan dengan cara menyari simplisia pada suhu $90^{\circ} \mathrm{C}$ selama 15 menit. Selanjutnya membuat variasi konsentrasi infusa 100\%, 50\%, 25\%, 12,5\%, 6,25\%. Pengujian dengan zona hambat infusa $E$. palmifolia terhadap pertumbuhan bakteri E. coli dilakukan dengan metode difusi menggunakan kertas cakram, adanya zona hambat ditandai dengan daerah bening di sekitar cakram. Hasil penelitian menunjukan infusa E. palmifolia mempunyai aktivitas menghambat bakteri E. coli dengan diameter zona hambat masingmasing konsentrasi $100 \%=0,94 \mathrm{~mm}, 50 \%=0,9 \mathrm{~mm}, 25 \%=0,82 \mathrm{~mm}, 12,5 \%=0,8 \mathrm{~mm}$ dan $6,25 \%=0,3 \mathrm{~mm}$. Konsentarasi $100 \%$ memiliki diameter zona hambat tertinggi dibandingkan dengan konsentasi lainnya. Hal ini menandakan bahwa aktivitas antibakteri pada konsentrasi $100 \%$ pada infusa simplisia E. palmifolia lebih tinggi yang dapat menghambat pertumbuhan bakteri $E$. coli meskipun perbandingan nilai nya tidak jauh berbeda dengan konsentrasi lainnya.
\end{abstract}

Kata Kunci : E. palmifolia, E. coli, Zona Hambat

\begin{abstract}
One of the plants that can be used for antibacterial is Dayak onion (Eleutherine palmifolia (L.) Merr.), A Kalimantan herbal plant which contains flavonoid, alkaloid, glycoside, phenolic, quinone, steroid, and tannin chemical compounds. These compounds have the ability to inhibit and kill bacterial activity. One of them is the Escherichia coli bacteria. E. coli usually lives in the intestines of humans and animals. The antibacterial test for E. palmifolia was carried out infusionly using a water solvent. This method is done by searching for simplicia at $90{ }^{\circ} \mathrm{C}$ for 15 minutes. Next make variations in the concentration of infusion $100 \%, 50 \%, 25 \%, 12.5 \%, 6.25 \%$. Tests with E. palmifolia infusion inhibition zone on the growth of E. coli bacteria were carried out by diffusion method using paper discs, the inhibition zone was marked by a clear area around the disc. The results showed that E. palmifolia infusion had inhibitory activity of E. coli with inhibition zone diameters of each concentration $100 \%=0.94 \mathrm{~mm}, 50 \%=0.9 \mathrm{~mm}, 25 \%=0.82 \mathrm{~mm}, 12.5 \%=0.8 \mathrm{~mm}$ and $6.25 \%=0.3 \mathrm{~mm}$. Concentration $100 \%$ has the highest inhibitory zone diameter compared to other concentrations. This indicates that the antibacterial activity at a concentration of $100 \%$ in infusions of E. palmifolia is higher which can inhibit the growth of E. coli bacteria even though the comparison value is not much different from other concentrations.
\end{abstract}

Keywords: E. palmifolia, E. coli, Inhibition Zone 


\section{PENDAHULUAN}

Suatu penyakit infeksi dapat disebabkan oleh bakteri, salah satu bakteri yang berperan dalam infeksi Escherichia coli. E. coli biasanya hidup di usus manusia dan hewan. Kebanyakan jenis bakteri E. coli tidak berbahaya bahkan membantu menjaga saluran pencernaan tetap sehat. Meskipun demikian, ada beberapa jenis bakteri E.coli tertentu yang dapat menyebabkan kram perut parah, diare berdarah dan gagal ginjal (Amanda, 2014).

Salah satu tanaman yang digunakan sebagai antibakteri adalah bawang dayak (Eleutherine palmifolia (L.) Merr.), merupakan tanaman herbal Kalimantan yang dimanfaatkan sebagai obat berbagai jenis penyakit. Kandungan senyawa kimia yang dimiliki bawang dayak ini berpotensi sebagai antibakteri adalah flavonoid, alkaloid, glikosida, fenolik, kuinon, steroid, dan tannin yang memiliki kemampuan menghambat dan mematikan aktivitas bakteri (Bilqis et al., 2018).

Tanaman E. palmifolia dapat digunakan sebagai antibakteri dengan cara ekstraksi. Ekstraksi merupakan proses pemisahan bahan dari campurannya dengan menggunakan pelarut yang sesuai. Ekstraksi dapat dilakukan dengan macam-macam metode yaitu metode infusa, maserasi, perkolasi dan sokletasi, tergantung dari tujuan ekstraksi, jenis pelarut yang digunakan dan senyawa yang dinginkan. Pada penelitian ini menggunakan metode infusa (Azwan, 2018).

Infusa merupakan suatu proses penyarian suatu senyawa kimia dari suatu bahan alam dengan menggunakan pelarut tertentu. Pada proses infusa digunakan E. palmifolia dalam keadaan yang telah dikeringkan. Pada penelitian ini menggunakan metode infusa, infusa hanya dapat menyari zat-zat kandungan yang aktif yang bersifat polar atau larut dalam air. Metode penyarian dengan cara menyari simplisia dalam air ini pada suhu $90^{\circ} \mathrm{C}$ selama 15 menit (Djamal, 2015).

Belum ada penelitian tentang infusa E. palmifolia sebagai antibakteri terhadap E. coli. Oleh karena itu, penelitian ini dilakukan 
untuk mengetahui adanya aktivitas antibakteri infusa pada tanaman $E$. palmifolia menggunakan beberapa variasi konsentrasi infusa secara bertingkat yaitu 100\%, 50\%, 25\%, $12,5 \%, 6,25 \%$ untuk menghambat pertumbuhan bakteri E. Coli (Hidayat, 2015).

\section{METODE PENELITIAN}

1. Sterilisasi basah, Bahan dan alat yang di sterilisasi dalam autoklaf yaitu media EMB, aquades dalam tabung erlenmeyer, tabung reaksi, dan tip. Bahan dan alat yang belum digunakan dibungkus dengan plastik tahan panas, lalu dimasukan dalam autoklaf selama kurang lebih 1-2 jam (Romadhon, Sterilisasi kering, Bahan dan alat yang di sterilisasi dalam oven seperti cawan petri, spatula dan pinset. Sebelum dimasukan ke dalam oven, dibungkus dengan kertas. Kemudian dimasukkan ke dalam oven kurang lebih 1 jam hingga mencampai suhu $150^{\circ} \mathrm{C}$ (Romadhon, 2016).
2. Pengambilan Sampel didapatkan penjual herbal pengerajin tanaman $E$. Palmifolia.Kemudian, sampel yang dimasukan kedalam wadah yang bersuhu normal. Sehingga, kondisi sampel dalam baik (Romadhon, 2016).

3. Pembuatan media uji dan penanaman sampel. Media EMB ditimbang sebanyak 1,5 gram, lalu dimasukkan ke dalam beaker gelas yang telah berisi $40 \mathrm{ml}$ aquades, kemudian panaskan pada hotplate selama \pm 15 menit $150^{\circ} \mathrm{C}$. Setelah itu masukkan ke dalam tabung erlenmeyer $250 \mathrm{ml}$, dan tutup dengan kapas. Kemudian sterilisasi di autoklaf selama \pm 1-2 jam. Lalu, tuang media kedalam cawan petri $( \pm 20 \mathrm{ml})$ dan dinginkan. Bila telah mengeras masukkan kedalam kulkas bersuhu $\quad 3^{\circ} \mathrm{C}$ (Romadhon, 2016).

4. Pembuatan stok bakteri dengan membuat suspensi bakteri yang dilakukan 
memperbanyak E. coli dengan cara mengambil 1 ose biakan murni bakteri E. coli dalam nutrien agar, kemudian diinkubasi pada suhu $36-37^{\circ} \mathrm{C}$ selama 24 jam di dalam inkubator.

5. Infusa bawang dayak Infusa dibuat dengan cara 100 gram serbuk simplisia pada tanaman E. palmifolia dimasukkan ke dalam $100 \mathrm{ml}$ akuades dalam erlenmeyer sehingga diperoleh konsentrasi $100 \%$.

Erlenmeyer diletakkan dalam gelas beaker berisi air dan dipanaskan di atas hot plate selama 15 menit dihitung mulai suhu $90^{\circ} \mathrm{C}$ sambil sesekali diaduk. Setelah 15 menit, air rebusan yang telah dingin disaring dengan menggunakan kertas saring steril ke dalam erlenmeyer steril. Untuk mencukupi kekurangan air, ditambahkan akuadessteril yang mendidih melalui ampasnya hingga volume mencapai $100 \mathrm{ml}$ (Rheza, 2015).
6. Pembuatan variasi konsentrasi esktrak larutan konsentrasi $100 \%$ dibuat dengan cara mengambil $4 \mathrm{ml}$ larutan uji dan dimasukan kedalam botol vial dan diberi label $100 \%$. Larutan tersebut kemudian diencerkan dengan menambahkan aquades hingga membentuk konsentrasi masing-masing $100 \%, 50 \%, 25 \%, 12,5 \%$, 6,25\% (Rheza, 2015). Pengulangan perlakuan ini menggunakan rumus Federer:

$$
(\mathrm{n}-1)(\mathrm{t}-1) \geq 15
$$

Keterangan:

$\mathrm{n}=$ jumlah ulangan

$\mathrm{t}=$ jumlah perlakuan

(Saridewi et al., 2017).

7. Pengujian daya hambat infusa E. palmifolia terhadap pertumbuhan bakteri E.coli dilakukan dengan metode difusi menggunakan kertas cakram berdiameter 6 mm.Tahapan awal yang dilakukan yakni swab kapas steril dicelupkan ke dalam suspensi bakteri E. coli yang telah disesuaikan kekeruhan 
suspensi inokulumnya selama 15 menit, kemudian swab diputar beberapa kali dan ditekan ke dinding tabung di atas cairan untuk menghilangkan inokulum yang berlebihan dari swab. Setelah itu, bakteri E. coli diinokulasikan pada permukaan media EMB dengan melakukan streaking di seluruh permukaan media. Prosedur diulangi dengan melakukan streaking dua kali lebih banyak, diputar sekitar $60^{\circ}$ untuk memastikan pemerataan inokulum. Tahapan berikutnya yakni kertas cakram yang telah direndam dalam larutan sampel infusa E. palmifolia, kontrol positif eritromsin 15 $\mu \mathrm{g} /$ disk, dan kontrol negatif aquades steril selama 15 menit ditempatkan pada permukaan lempeng EMB yang telah diinokulasi bakteri uji menggunakan pinsetsteril. Setelah itu, baru masingmasing kertas cakram berukuran $6 \mathrm{~mm}$ sebanyak buah diletakan di atas media EMB tersebut dengan jarak tiap cakram sebesar $3 \mathrm{~cm}$ dan dari tepi lempeng sebesar 2 $\mathrm{cm}$.

8. Analisis Data

Data hasil penelitian ini berupa aktivitas zona hambat anti bakteri. Metode analisis data dengan menggunakan statistik deskriptif. Statistik deskriptif digunakan untuk mendeskriptifkan data sampel uji aktivitas daya hambat antibakteri. Ukuran statistik yang digunakan dalam deskripsi pada penelitian ini yaitu berupa selisih, rata-rata, nilai tertinggi, dan nilai terendah dari hasil pengukuran. Penyajian data dari hasil pengukuran statistik, disajikan dalam bentuk tabel, grafik, dan gambar sebagai penyajian data yang komunikatif dan efesien yang kemudian dianalisis secara deskriptif (Yuniasih, 2018). 


\section{HASIL PENELITIAN}

Penelitian ini menggunakan perlakuan dengan 5 variasi konsentrasi infusa E. palmifolia yaitu $100 \%, 50 \%, 25 \%, 12,5 \%, 6,25 \%$ dilakukan pengulangan sebanyak 5 kali.

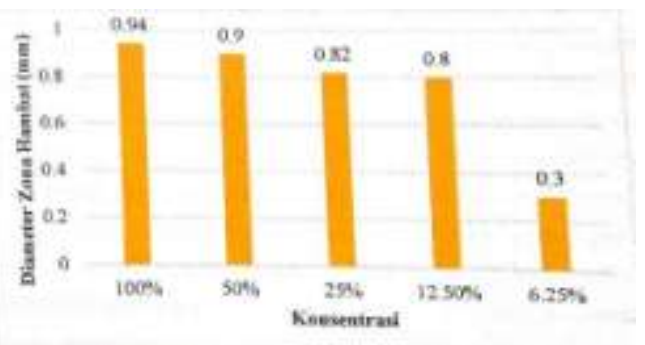

Gambar 5.2 Diagram Zona Hambat Pada Uji antibakteri infusa $E$. palmifolia Terhadap Pertumbuhan Bakteri E. coli

\section{PEMBAHASAN}

Penggunaan obat tradisional pada masyarakat indonesia saat ini semakin berkembang. Banyak masyarakat tertarik untuk mengobati segala berbagai macam penyakit yang diderita dengan pengobatan tradisional dari berbagai ragam tanaman obat indonesia. Salah satunya yaitu tanaman bawang dayak (Eleutherine palmifolia) yang dipercaya sebagai tanaman obat multifungsi untuk berbagai penyakit (Firdaus, 2014).

Metode yang digunakan dalam uji antibakteri ini yaitu metode difusi cakram kertas. Metode ini dilakukan dengan meletakkan cakram kertas yang telah direndam larutan uji di atas media padat yang telah diinokulasi dengan bakteri. Pencelupan cakram pada larutan uji hingga seluruh permukaan cakram basah. Pengamatan dilakukan setelah bakteri diinokulasi, pertumbuhan bakteri diamati untuk melihat zona bening disekitar cakram. Pemilihan metode ini karena mudah dan sederhana untuk menentukan aktivitas antibakteri sampel yang di uji. Kertas cakram yang digunakan berdiameter $0,5 \mathrm{~cm}$ (Mulyadi et al., 2017).

Bakteri harus diinkubasi pada suhu sekitar $37^{\circ} \mathrm{C}$ karena bakteri yang akan diperiksa adalah bakteri yang masuk kedalam tubuh, sehingga bakteri ini pun berasal dari mahluk hidup yang suhunya kisaran 37 hingga 
$38^{\circ} \mathrm{C}$. Selain itu bahan uji adalah bahan pangan yang akan dikonsumsi manusia sehingga suhu disesuaikan salah satunya selama 18-24. Pengamatan dengan cara mengukur zona bening yang terbentuk menggunakan jangka sorong, sehingga dapat disebut dengan zona hambat.

$$
\text { Dali, dkk }
$$

menjelaskan bahwa terdapat beberapa faktor yang mempengaruhi besar kecilnya zona hambat pada bakteri. Faktor-faktor tersebut adalah kepekaan pertumbuhan, reaksi antara bahan aktif dengan medium dan suhu inkubasi, $\mathrm{pH}$ lingkungan, komponen media, kerapatan koloni, waktu inkubasi dan aktivitas metabolic mikroorganisme. Faktor lain yang mempengaruhi besar kecilnya luas zona bening adalah jumlah kandungan zat aktif yang terdapat dalam larutan tersebut. Zona hambat merupakan daerah jernih di sekitar sumuran yang dapat menunjukkan bahwa adanya aktivitas bakteri yang dihambat. Zona hambat dapat dilihat akan membentuk bulat warna putih bening. Zona hambat yang terbentuk pada penelitian ini disebabkan oleh adanya kandungan alkaloid, steroid, glikosida, fenolik, flavonoid, tanin dan saponin yang bersifat sebagai anti bakteri. Mekanisme anti bakteri yaitu dengan cara merusak dan menghambat pertumbuhan pada bakteri sehingga bakteri tidak bisa tumbuh sempurna.

Pengujian antibakteri dilakukan dengan metode disc diffusion (tes Kirby-Bauer). Ose steril dimasukkan ke dalam tabung reaksi yang berisi suspensi bakteri kemudian dioleskan pada media NA. Setelah olesan bakteri mengering, paper disk (diameter $6 \mathrm{~mm}$ ) yang telah direndam ekstrak selama 1 jam ditiriskan dan diletakkan di atas media yang berisi olesan bakteri dengan sedikit ditekan agar paper disk menempel pada permukaan media. Selanjutnya diinkubasi pada suhu $37^{\circ} \mathrm{C}$ selama $24-48$ 


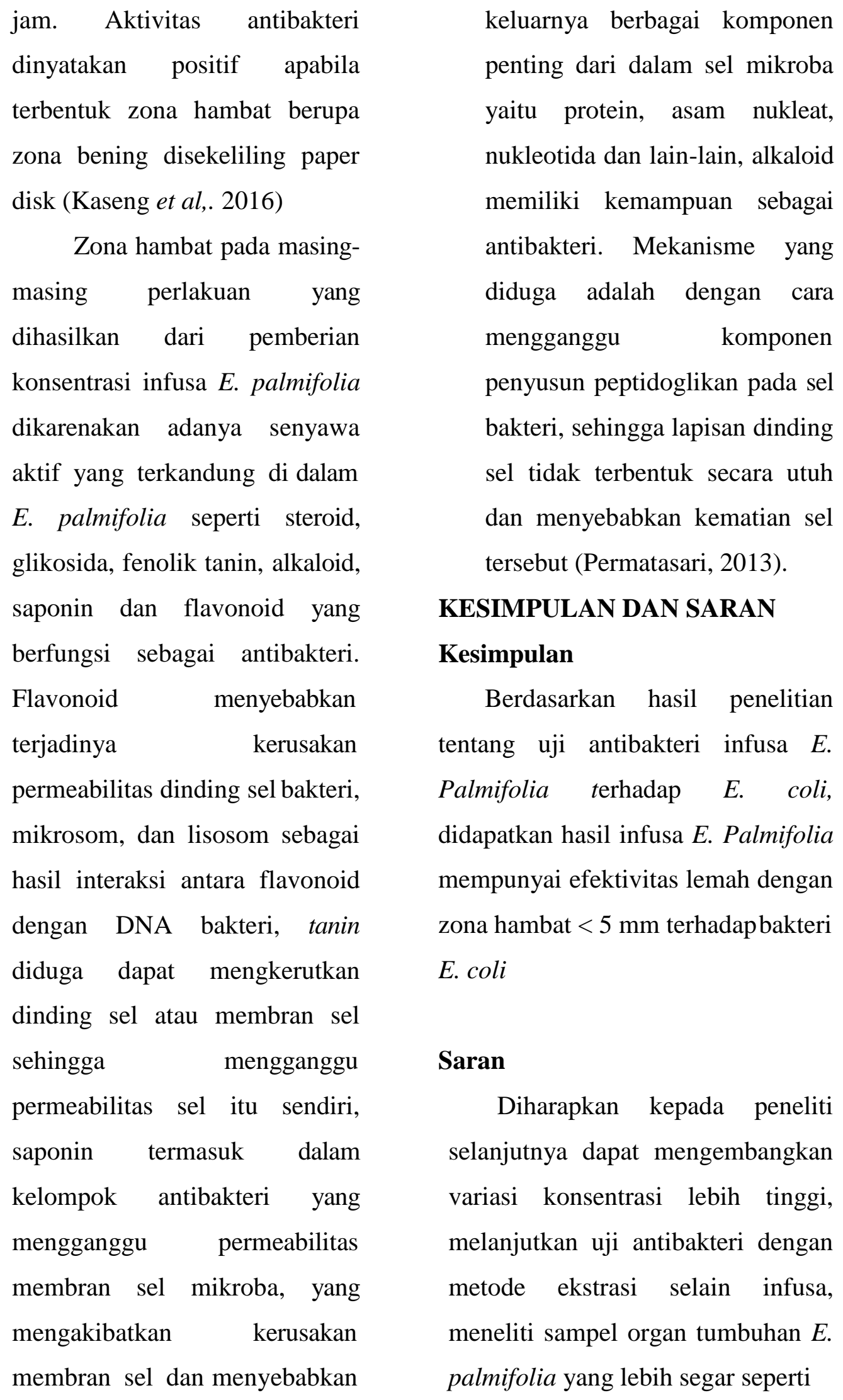


daun, buahnya atau akarnya supaya didapat manfaat yang berguna bagi masyarakat luas

\section{DAFTAR PUSTAKA}

Amanda, F. R. 2014. Efektivitas Ekstrak Bawang Dayak Eleutherine palmifolia (L). Merr Dalam Menghambat Pertumbuhan Bakteri E. coli. Skripsi. Universitas Islam Negeri. Jakarta

Azwan. 2018. Uji Efektivitas Ekstrak Bawang Dayak (Eleutherine Palmifolia L.) Terhadap Pertumbuhan Staphylococcus aureus Isolat Pus Infeksi Odontogenik. Skripsi. Universitas Sumatera Utara. Medan.

Bilqis, M. dan I. Erlita. 2018. Daya Hambat Ekstrak Bawang Dayak (Eleutherine palmifolia (L.) Merr.) Terhadap Pertumbuhan Bakteri Lactobacillus ccidophilus. Dentin Jurnal Kedokteran Gigi. 11 (1): 2631.

Djamal, M. 2015. Paradigma Penelitian Kualitatif. Pustaka Pelajar. Yogyakarta.

Mulyadi, M. Wuryanti dan P. R. Sarjono. 2017. Konsentrasi Hambat Minimum (KHM) Kadar Sampel Alang-Alang (Imperata cylindrica) dalam Etanol Melalui Metode Difusi Cakram. Jurnal
Kimia Sains dan Aplikasi. 20

(3) : $130-135$.

Permatasari., Besung dan Mahatmi. 2013. Daya Hambat Perasan Daun Sirsak Terhadap Pertumbuhan Bakteri Escherichia coli. Jurnal Indonesia Medicus Veterinus. 2 (2).

Rheza, M. 2015. Uji Aktivitas Antibakteri Infusa Daun Mangga Bacang (Mangifera foetida L.) Terhadap Pertumbuhan Shigella flexneri. Skripsi. Universitas Tanjung Pura. Pontianak.

Romadhon. Z. 2016. Identifikasi Bakteri Escherichia coli dan Salmonella Sp Pada Siomay Yang Dijual Di Kantin SD Negeri Di Kelurahan Pisangan, Cirendeu, dan Cempaka Putih. Skripsi. Universitas Syarif Hidayatullah. Jakarta.

Saridewi, N. M. M. Bahar dan Anisah. 2017. Uji Efektivitas Antibakteri Perasan Jus Buah Nanas (Ananas comosus) Terhadap Pertumbuhan Isolat Bakteri Plak Gigi di Puskesmas Kecamatan Tanah Abang Periode April 201. Journal.uin-alauddin.ac.id. 5 (2): 104-110.

Syamsul Hidayat. 2015. Uji Aktivitas Antibakteri Infusa Daun Mangga Bacang (Mangifera foetida L.) Terhadap Staphylococcus aureus Secara 
In Vitro. Skripsi. Universitas

Tanjung Pura. Pontianak.

Yuniasih, M.M. 2018. Pengaruh

Daya Hambat Antimikroba

Isolat Alkaloid Umbi Bawang

Dayak

(Eleutherine

palmifolia) terhadap

pertumbuhan Eschericia coli,

Staphylococcus epidermis dan

Candida albicans ATCC

10231 secara In Vitro. Skripsi.

Universitas Sanata Dharma.

Yogyakarta. 